\title{
Changes in Wealth and the Velocity of Money
}

\author{
G. J. Santoni
}

$\mathrm{NE}$ long-standing view among economists is that the quantity of money in circulation and aggregate income are closely related in the long run. ${ }^{1}$ This relationship, known as the income velocity of money, is particularly important because it makes it possible to determine the effect of changes in money growth on income over extended periods. ${ }^{2}$

Unfortunately, this relationship has not behaved well in recent years. Various investigators have attempted to identify the reasons for this unusual behavior, focusing on institutional changes that allowed the payment of interest on transaction deposits, the rise in the trade deficit, and changes in tax rates. ${ }^{3}$ In general, however, their results have been inconclusive.

This article discusses how changes in wealth can affect velocity and considers whether the atypical be-

G. J. Santoni is a senior economist at the Federal Reserve Bank of St. Louis. Thomas A. Pollmann provided research assistance.

"See, for example, Fisher (1963) who notes that: "This theory, though often crudely formulated, has been accepted by Locke, Hume, Adam Smith, Ricardo, Mil, Walker, Marshalt, Hadley, Fetter, Kemmerer, and most writers on the subject." (p. 14) See also pp. $157-59$ and 296-97. More recent examples are Friedman and Schwartz (1963 and 1982). Thornton (1983) presents a nontechnical discussion of the theory.

zUsing monetary policy to hit short-run stabilization objectives is problemmatical if not impossible. See Thornton (1983) and Mankiw and Summers (1986), p. 419, for discussions of this point.

3Rasche (1986), Mankiw and Summers (1986), Tatom (1983), Taylor (1986), Siegel and Strongin (1986) and Kopcke (1986) represent some of the recent attempts to resolve the issue. havior that velocity has exhibited in recent years can be attributed to changes in wealth. ${ }^{4}$

\section{VELOCITY: A MEASURE OF THE RELATIONSHIP BETWEEN MONEY AND SPENDING}

The most commonly used measure of the relationship between income and the stock of money is the income velocity of money. It is the ratio of GNP to M1 (the sum of currency in the hands of the public and checkable deposits).

Chart 1 plots the income velocity of money from $\mathrm{L}$ 1959 through III/1986. As indicated, this measure has risen fairly steadily throughout most of the period. Before 1982, the growth rate of income velocity was remarkably stable, averaging about 3 percent peryear." Hence, the average annual growth rate of GNP exceeded the average annual growth rate of the quantity

\footnotetext{
4See Knight (1941), Friedman (1956) and Meltzer (1963) for examples of this argument.

5 The average annualized growth rate was 3.13 percent with a standard deviation of 4.03 . The standard deviation is a measure of the variation in velocity growth around its average. Short-run changes in velocity growth have been attributed to cyclical factors, changes in the pattern of receipts and payments, financial introvations and changes in the nominal interest rate. See, for example. Fister (1963), pp. 58-73, Tatom (1983) and Thomton (1983), p. 10.
} 


\section{Chart 1}

\section{Income Velocity}

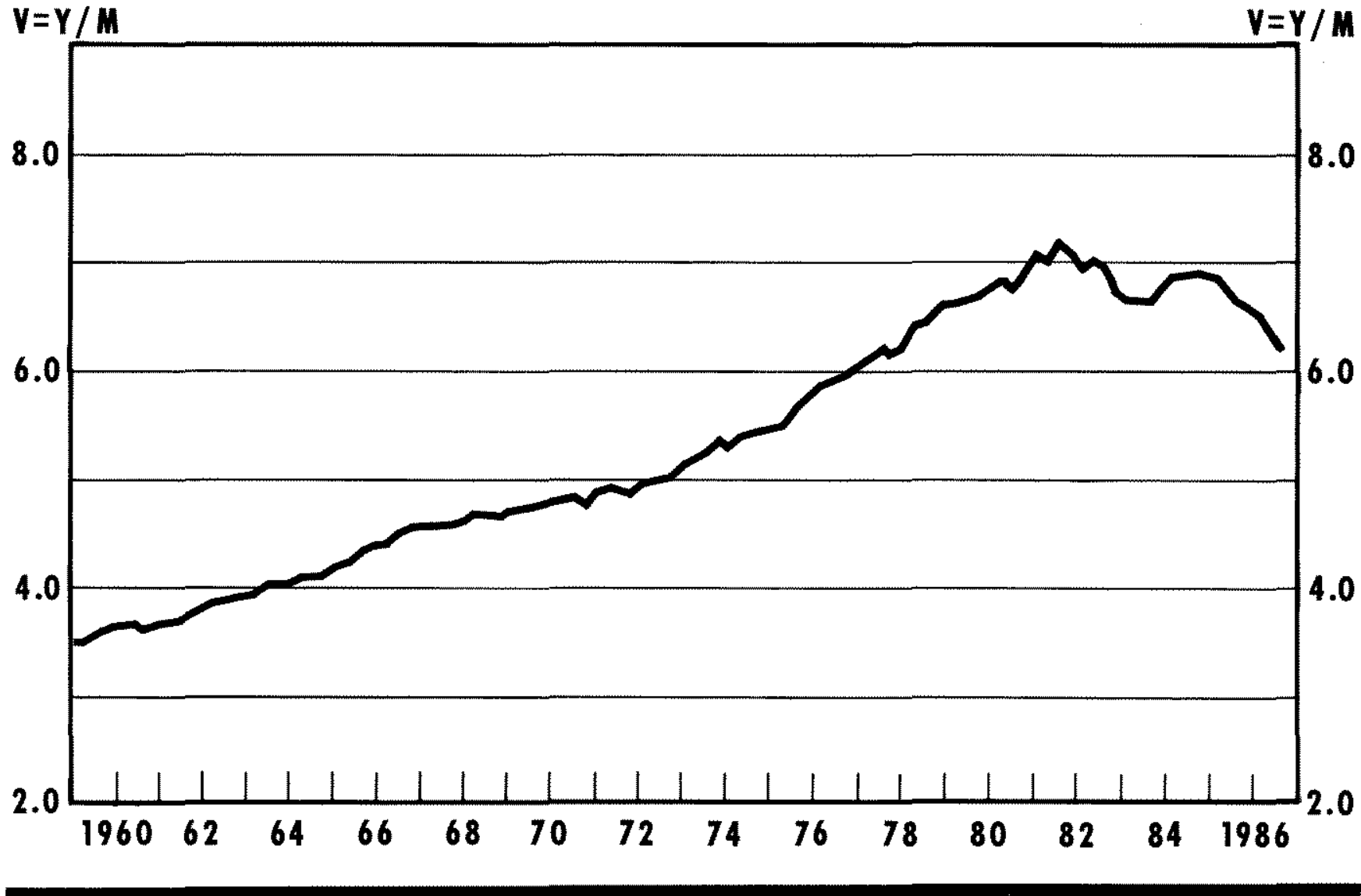

of money by about 3 percentage points. ${ }^{6}$ In recent years, however, velocity growth has changed considerably. As chart 1 indicates, velocity generally has declined at an annual average rate of about 3.0 percent since the end of $1981{ }^{7}$

If monetary policymakers were certain that the long-run average growth in velocity had changed per-

6if $V$ is the income velocity of money while $Y$ and $M$ are GNP and the quantity of money, then $\mathrm{V}=\mathrm{Y} / \mathrm{M}$. This equation can be written in growth rate form as below. The dots over the variables indicate compounded annual growth rates.

$$
\dot{V}=\dot{Y}-\dot{M}
$$

Since $\dot{V}$ averaged about 3 percent before $1982, \dot{Y}$ exceed $\dot{M}$ by about 3 percentage points on average.

The break in velocity growth has been dated at the end of 1981 . See Rasche (1986), pp. 2 and 8 . The average annualized growth rate in velocity during $\mathrm{I} / 1982-111 / 1986$ was -2.9 percent with a standard deviation of 5.67 . manently from +3 percent per year to -3 percent per year, they could, once again, determine the impact of any given long-run growth in M1 on GNP. There is considerable uncertainty, however, about whether the change in velocity's average growth is permanent or only temporary. Identifying the reasons for the recent declines might help resolve this issue.

\section{VELOCITY AND MONEY DEMAND}

Velocity relates the equilibrium level of income to the equilibrium quantity of money; the latter depends importantly on the quantity of money demanded. ${ }^{s}$ Momentarily ignoring other things that may influence people's choices, money demand theory states that the demand for money is proportionally related to

'See Friedman (1956), p. 4. 
some scale variable, either income or wealth. The transaction theory of money demand uses the flow of current income as the scale variable while the portfolio approach to money demand uses the stock of wealth."

\section{The Transaction Approach to Money Demand}

The transaction approach presumes that money is held to support current spending and that current spending is closely related to current income. This theory relates the demand for money $\left(\mathrm{M}^{\mathrm{D}}\right)$ to current income $(\mathbf{Y})$ by some proportion $(\mathbf{k})$. In equilibrium, since the quantity of money demanded is equal to the quantity supplied $\left(M^{p}=M^{s}=k Y\right)$, the ratio of income to the quantity of money (income velocity) is equal to the inverse of this proportion $\left(\mathrm{V}=\mathrm{Y} / \mathrm{M}^{\mathrm{s}}=\mathrm{Y} / \mathrm{kY}=1 / \mathrm{k}\right)$. If current income rises, desired spending rises in proportion; consequently, people will want more money to facilitate their increased spending.

The transaction approach has an important advantage from an empirical point of view. The data on income are relatively good and readily available. What's more, numerous empirical tests of the theory have been conducted, and the empirical relationships between money and income have performed well during certain time periods..$^{10}$ There have been occasions, however, when they have broken down. Various analysts have pointed to breakdowns in the mid-1960s, when velocity fell unexpectedly, in the mid-1970s, when it rose unexpectedly, and, in recent years, when it has fallen again unexpectedly. ${ }^{13}$

\section{A Portfolio Approach to Money Demand}

An alternative theory of money demand suggests that the quantity of money balances that people hold is related more closely to their wealth than their current income. ${ }^{22}$ Money is simply one of many assets in

\footnotetext{
The transaction approach includes other variables besides current income in the money demand function. These are mentioned below. See Laidier (1985), pp. 49-97, for a more complete discussion of the various approaches to money demand.

10See Laidler ( 1985 ), pp. 117-34.

1 Few people dispute the importance of the recent breakdown. There is some disagreement, however, regarding the significance of the earlier breaks. See Judd and Scadding (1982), Laidler (1985), pp. 135-51, and Rasche (1986), p. 7, for a discussion of the eatlier breaks.

12 See Knight (1941) and Friedman (1956), pp. 4-5. Knight, for example, argues that "The economic process in a pecuniary economy involves the holding or owning, by somebody, of wealth - all the
}

which wealth may be held. The desired mix of assets that make up wealth depends on both the net benefits of holding wealth in the various forms and risk preferences. The portfolio theory states that an increase in wealth is associated with an increase in the quantity of money people want to hold and vice versa.

Again, ignoting other factors that may influence choices, this theory says that the demand for money is a constant proportion (0) of wealth $(W)^{13}$ In equilibrium, the quantity of money demanded is equal to the quantity supplied; thus, the ratio of wealth to money (wealth velocity) is equal to the inverse of this proportion $(W / M=W / g W=1 / 0)$.

\section{The Difference between the Two}

Both theories of money demand agree that certain variables, such as short-term interest rates, population, the pattern of receipts and payments, the technology of the payment system and risk preferences, are important for money demand. They differ, however, in regard to the scale variable.

If current income were always a constant proportion of wealth, there would be no substantive empirical difference between the two theories. In this case, $\theta$ and $k$ would differ by a constant factor that reflects the ratio of income to wealth $[\mathrm{V}=1 / \mathrm{k}=\mathrm{Y} / \mathrm{M}=$ $(W / \mathrm{M})(\mathrm{Y} / \mathrm{W})=(1 / 0)(\mathrm{Y} / \mathrm{W})]$. If income is not a constant proportion of wealth, however, and if the portfolio theory of money demand is correct, income velocity will fluctuate whenever current income changes relative to wealth. If current income rises relative to wealth, for example, the income velocity of money will rise also, other things the same. The reverse movement in the income velocity of money would occur if wealth rises relative to current income.

\section{Two Important Conditions}

The above discussion indicates that two conditions must hold if changes in wealth relative to income are important in explaining the decline in velocity since

\footnotetext{
wealth of the economy - and also the entire stock of money. Hence every property owner has the alternative either of holding money up to the amount of his fortune or of choosing the concrete kind of weasth other than money he will hold." (p. 210)

The portfolio theory does not necessarily imply a constant proportional relationship between money and wealth. This is an empirical question. See Laidler (1985), p. 58. There is evidence that the relationship is proportional for at least some wealth proxies. See, for example, Mankiw and Summers (1986) and Meltzer (1963). It is assumed to be proportional above for illustrative purposes.
} 
the end of 1981: 1) the demand for money must be more closely related to wealth than to current income (that is, wealth is the appropriate scale variable); 2) wealth must have risen relative to cument income since 1981.

Although the choice of the appropriate scale variable is still an unresolved issue among economists, it is useful to determine whether the second condition holds. If wealth has not risen relative to current income since 1981, whether the first condition holds or not is irrelevant; we can conclude that changes in wealth do not help explain the recent decline in velocity. On the other hand, if wealth has risen relative to current income, resolving the first issue becomes more important.

\section{WHAT IS WEALTH?}

To see why the ratio of current income to wealth may vary, it is helpful to understand how they are related.

An individual's wealth is the market value of his net assets; this market value is found by adding together the present values of all his assets and subtracting the sum of the present values of all his liabilities. This difference is equal to the present value of the expected stream of net receipts (income minus expenses). In the simplest case, it is the expected net income flow divided by the long-term interest rate. ${ }^{14}$ Thus, an individual's wealth at any time depends on both the expected future flow of net income and the relevant long-term interest rate.

\section{The Effect of Current Income on Wealth and Vice Versa}

Current income is the actual amount of income received each period. Because unanticipated events influence the income actually received, current income generally differs from the income expected for any period. The difference between current and ex pected income is called transitory income.

Since wealth is the present value of the expected future income flow, transitory income has only a small

\footnotetext{
See Fisher (1954), pp, 12m-13, and Friedman (1956), pp. 4-5. Fisher, for example, defines wealth (or capital value) as "simply future income discounted or, in other words, capitalized. The value of any property, or rights to wealth, is its value as a source of income and is found by discounting that expected income. . The bridge or link between income and captal is the rate of interest." (emphasis in original)
}

effect on wealth. For example, suppose a person receives a surprise Christmas bonus of $\$ 2,000$. If the person's annual income is $\$ 20,000$, the bonus is 10 percent of current income, a fairly large percentage. If however, the person does not associate the bonus with a change in his future income prospects, and his wealth before the bonus was $\$ 200,000$, the effect of the bonus on his wealth is relatively small ( 1 percent of wealth).

Another way to view this is to note that the individual's "permanent income" is not much affected by the bonus. Permanent income is the amount of consumption that can be sustained without changing wealth. Permanent income and wealth are closely related. ${ }^{15}$ In the above example, if the person consumed $\$ 22,000$ in the year the bonus is received, he would necessarily have to reduce his consumption in the following year or draw down his wealth, other things the same.

Suppose the person in this example is promised an increase in his annual salary beginning some time in the future. His wealth increases immediately upon learning of the prospective raise, other things the same, and his expected stream of future income is now higher, even though his current income does not yet reflect the raise. A decline in the interest rate induces a similar increase in wealth, other things the same, because it increases the present value of the unchanged stream of expected future income; current income, again, is unchanged.

While these examples refer to individuals, the argument applies to the whole community as well. Unexpectedly good havests, favorable relations between unions and management, or tranquil foreign relations can produce positive transitory components of income for the whole community. A reduction in trade barriers or changes in the tax laws that result in more productive use of resources can raise the expected future flow of aggregate income and, thus, raise wealth relative to current income. Finally, a decline in the level of interest rates can raise the present value of a given expected future flow of aggregate income; this increase in wealth occurs without affecting the current or expected future levels of income.

\footnotetext{
isee Friedman (1956), p. 5. For a perpetuat stream of income that is expected to increase at a constant rate $(\rho)$, wealth is$$
w=y_{0}(1+\rho) /(r-\rho)
$$

where $y_{0}$ is the initial income receipt and $r$ is the real interest rate $(r>p)$. Permanent income is $y^{*}=r w$. Wealth and permanent income are constant across time as long as $r$ and $\rho$ are constant and saving is zero. Expected income in period $n$, however, is $y_{n}=y_{0}(1+\rho)$.
} 
As the above discussion suggests, the ratio of current income to wealth generally is not a constant. Thus, if wealth is the appropriate scale variable for money demand, velocity will vary as the ratio of current income to wealth varies.

\section{MEASURING NATIONAL WEALTH}

Since we are concerned with the relationship between wealth and society's demand for money, we need to establish a concept of national wealth. Nam tional wealth is simply the aggregate wealth of the nation's residents. "There are two theoretically equivalent methods of measuring national wealth: the income and balance sheet methods.

\section{The Income Approach}

National wealth, in theory, can be measured by discounting the expected stream of net national in come by the appropriate interest rate. Some practical problems must be dealt with, however, when applying this method of measuring national wealth. One obvious problem is that the expected stream of income is not directly observed. Only current and past incomes are known. Thus, practical applications of the income method must depend on good estimates of the expected stream of net national income.

Many studies have used univariate time-series methods to estimate the expected stream of future income. ${ }^{\text {t7 }}$ Roughly, time-series models account for patterns in past movements of a particular variable (national income, in this case) and use the information contained in the pattern to predict future values of the variable. In a sense, a time-series model is a sophisticated method of extrapolation. ${ }^{18}$

While these models are a useful estimating tool, they have a serious drawback. When using them, the investigator must assume that the underlying economic structure that generated the observations will remain unchanged during the period of analysis. For example, a time-series model is not designed to forecast changes in the stream of future income that are produced by significant technological changes, institutional changes such as a major shift in the tax law, or

\footnotetext{
:See Goldsmith (1968), p. 51.

7 See Laidler (1985), pp. 88-90.

${ }^{18}$ See Pindyck and Rubinfeld (1981), p. 470.
}

significant changes in relative supplies such as produced by OPEC production quotas.

Another problem concerns the interest rate that is appropriate for discounting expected national income. National income is the sum of wages, rents and profits. Wage income, which accounts for about 75 percent of national income, is produced by human capital while nonhuman capital is the source of rents and profits. Unfortunately, the interest rate that is relevant in discounting the expected stream of wage income $\left(i_{h}\right)$ is not observable; moreover, because human capital is not as liquid as nonhuman capital, $i_{\text {月 }}$ is probably higher than the interest rate that applies to income produced by nonhuman capital $\left(i_{k}\right)$. If expected wages are discounted at the lower rate $i_{k}$, national wealth will be overstated. ${ }^{20}$ Of course, percentage changes in the wealth estimate will not be distorted as long as the ratio of $i_{\mathrm{H}}$ to $\mathrm{i}_{\mathrm{k}}$ does not change. Empirical estimates that depend on a constant relationship between these two interest rates, however, will produce misleading results whenever this ratio changes substantially.

\section{The Balance Sheet Approach to Estimating Wealth}

Some investigators have estimated national wealth using the balance sheet approach. ${ }^{23}$ This measure is obtained by summing the present values of the assets owned by U.S. residents and subtracting the sum of the present values of all the liabilities owed by U.S. citizens.

When these assets and liabilities are aggregated, all claims of one U.S, citizen against another U.S. citizen cancel out. Since most liabilities of U.S. citizens are owed to other U.S. citizens, these liabilities and their asset counterparts disappear from the aggregation. What remains is national wealth. It includes nonreproducible and reproducible tangible assets such as land, buildings, structures, machinery, vehicles, consumer durables, inventories (of raw materials, work in

\footnotetext{
${ }^{19}$ See Friedman (1956).

20 The only interest rates that are directly observable are those that apply to financial instruments. Consequently, neither $i_{H}$ or $i_{k}$ are directly observable. The capital asset pricing theory developed in the finance literature, however, can be used to produce estimates of $i_{k}$.

21See Goldsmith (1968). In theory, the balance sheet and income approaches to measuring weatth are equivalent. But there are numerous practical problems that arise. "These are discussed below.
} 


\section{Should Government Bonds and the Money Stock Be Included in Wealth?}

\section{Government Deht}

The market valie of domestic govermment debt that is held by domestic citizens is sometimes included in national wealth estimates. Presenty, however, there seems 16 he rib agreement anomg professional economists about whether it belongs in the weallh aggregate. On one side of the argument goveimment bonds are like olther financial instruments, assets to the ereditor and Labilities to the debtor. The creditor's Weallh in govermment bonds is equal to the present value of the expected strean of future receipts of interest and primcipal. The debtors are the taxpayers who must pay the funire taxes obligated by the bond interest and principal payments. In theory the present value of the taxpayers' liability offsets the eneditors' wealth in the bonds, It is unclear, however, whether taxpaversactually take account of the future tax liabiltiy obligated by the bonds. If these liabilities are wholly or partially ignored, an increase in the present value of outstanding government honds causes people to behave as if their wealth has increased.

\section{The Morrey Stock}

Outside money is ribney issued by sovereign govemments; if consists of notes and coins issued by foneigh govermments, as well as U.S. Treasury coin

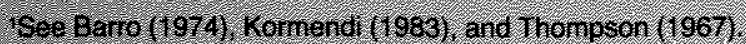

and Federal Reserve notes. Outside money is typically inctuded in national wealth since if is an asser to the holder and is not offset by any domestic taxpaver liability.

Instde money is the sum of checkable deposits issued by depository institutions. These deposits represent about 75 percent of Mi balances. Though these deposits are patt of the wealth of the people. who hold the deposits, they must be redeemed by the bank on demand of the depositor necause of this provision, some economists view these deposits as liabilities for the owners of depository institutions. Consequently, in this view Inside money is like other domestic financial instriments: if represents a claim by one citizen on another, and these claims cancel in compuling national wealth:

Some investigators have argued that he distine. fion between inside and oulside noney is intelevant They suggest that checkable deposits are the output of the banking system in the same sense that autos are the outpul of the notor vehicle industry. In their view, inside money, like autos, is a compo: nent of national Wealih:

While economists generally agree that outside money is part of wealth. there is no general agree: inent about inside money. see Patinkin $(1965), 0.15$

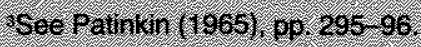

5seo pesck and Saving 1067 . process and finished goods), military assets, works of art, human capital and net claims on foreigners."2 Most investigators who estimate national wealth by the balance sheet method agree that the above items belong in national wealth. There is some disagreement, however, about which other things should also be included. These controversial items are discussed in the shaded box above.

22See Goldsmith (1968), p. 52.
The balance sheet method of estimating national wealth is costly because it requires an extensive inventory of the nation's assets and liabilities. As a result, estimates of national wealth that employ this method are available only on an annual basis.

There are several other problems with this method. ${ }^{23}$ It requires that assets and liabilities be val-

asee Goldsmith (1968), pp. 52-54, for a further discussion of the practical problems of applying this method. 
Chart 2

\section{Expected Income and Physical Wealth}

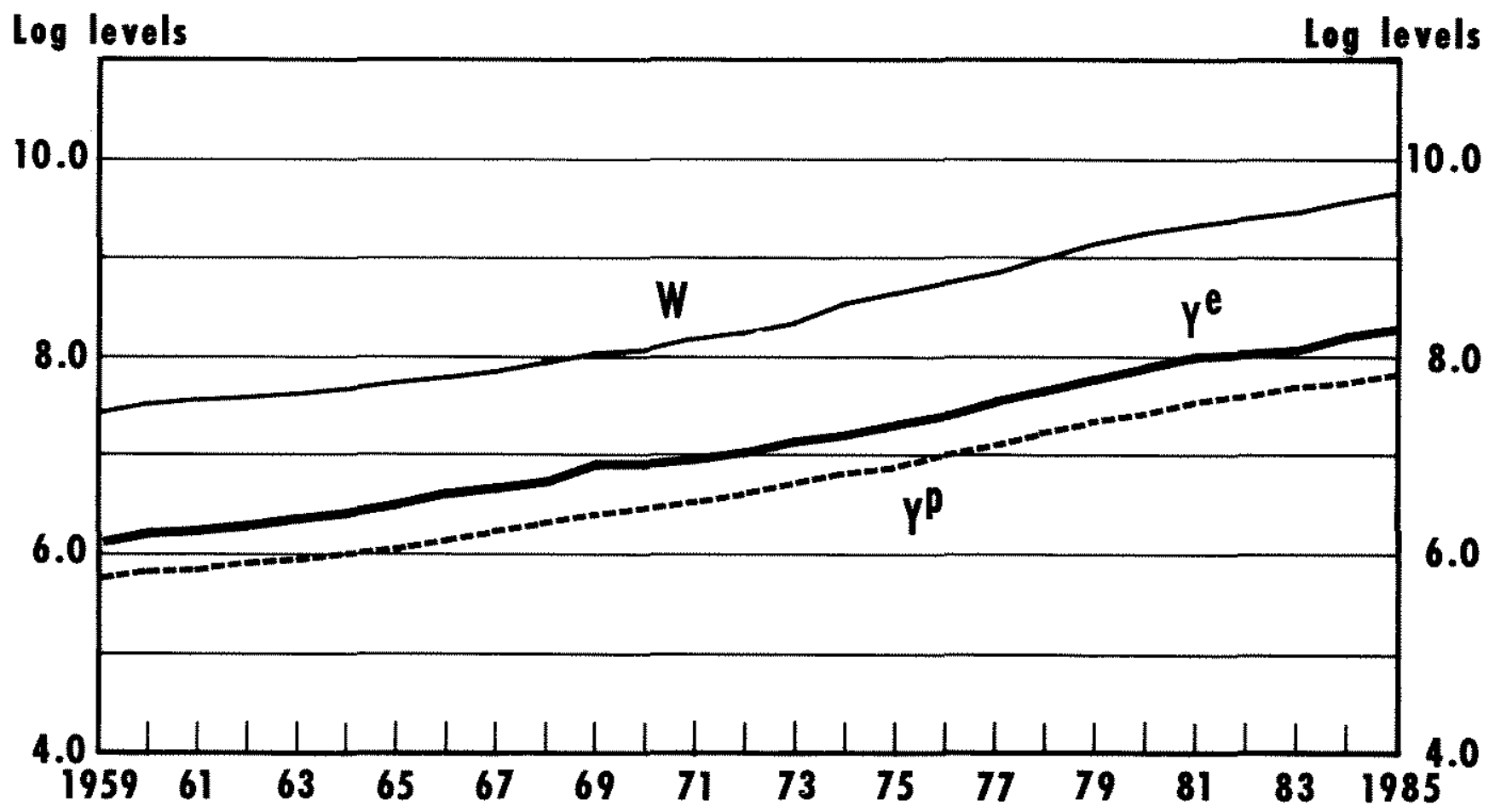

ued at their market prices. Many assets, however, are traded infrequently, if at all. For example, the discounted value of people's wages is never traded in markets, yet this makes up a substantial part of everyone's wealth. There are many privately held businesses, unique pieces of real estate and personal property that are infrequently traded; consequently, it is difficult to obtain accurate assessments of their market values.

In practice, measurements of national wealth based on the balance sheet method depend on estimates of market values. Reproducible assets are valued at their replacement cost net of straight-line depreciation, land holdings are valued at assessed market prices and no estimates are made of the value of human

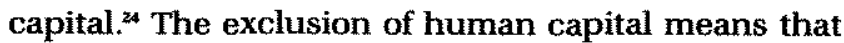
estimates of national wealth seriously understate the actual wealth of the nation.

${ }^{24}$ See for example, "Balance Sheets for the U.S. Economy 1946-85," p. 1.

\section{HAS WEALTH RISEN RELATIVE TO CURRENT INCOME?}

Empirical studies that test the portfolio theory have used various empirical measures for national wealth. In most cases, the studies have based the wealth estimates on either the income or balance sheet approach to measuring wealth. ${ }^{25}$

Various empirical estimates of money demand have used three different scale variables as proxies for national wealth: expected income, permanent income

25ome studies have used "financial wealth" as an empirical measure of national wealth. Financial wealth is the sum of "household and business deposits and credit market instruments." This measure bears little theoretical relationship to the measures of national wealth discussed above. it is largely composed of claims by one U.S. citizen on another, claims that cancel when national wealth is calculated. As a result, it is difficult to interpret empirical estimates that employ this wealth proxy, so they are ignored in the following analysis. See, for example, Kopcke (1986), p. 19, and Friedman (1978), p. 625, note b. 


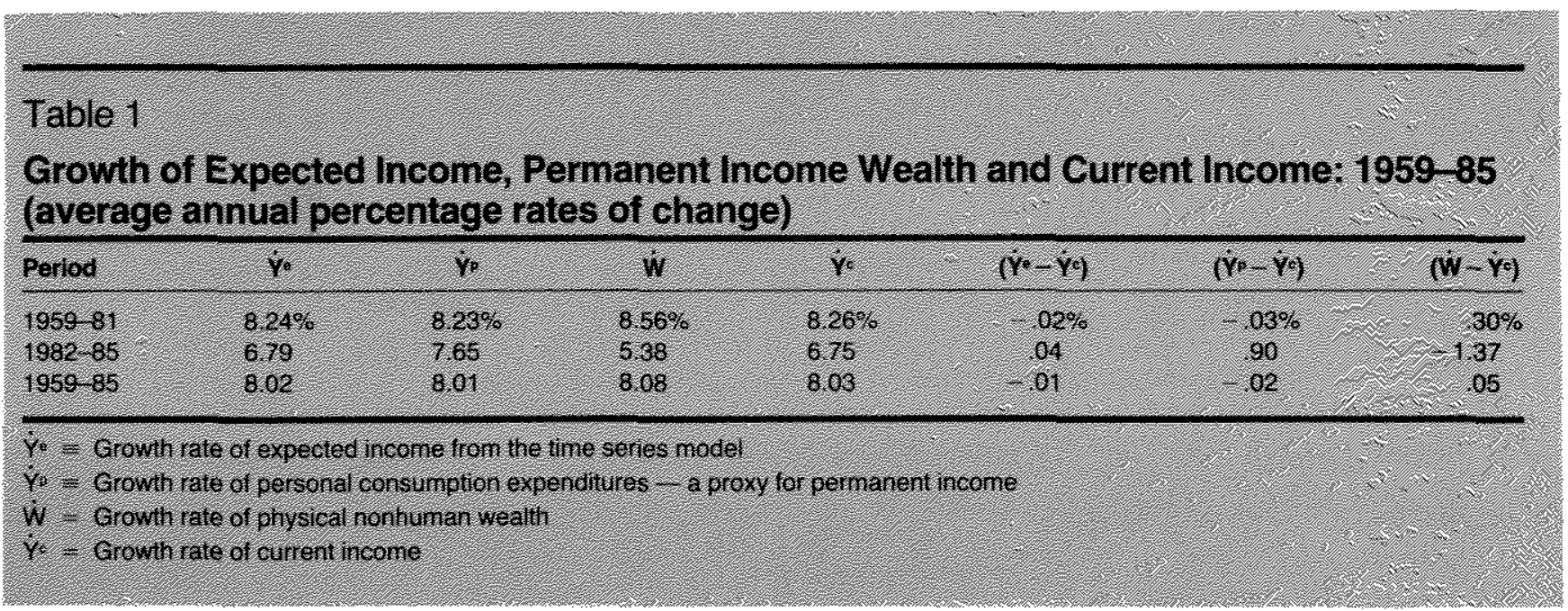

and physical nonhuman wealth taken from balance sheet data ${ }^{26}$ These proxies are examined to determine whether they have risen relative to current income since 1981 .

Chart 2 plots the logarithms of expected income ( $\left.Y^{e}\right)$, permanent income $\left(Y^{p}\right)$ and physical nonhuman wealth $(W)$. The time-series model used to estimate expected income is given in the appendix. Personal consumption expenditures are used as a proxy for permanent income. Finally, physical nonhuman wealth is estimated from balance sheet data and includes an estimate of the market value of federal government debt. 28

Chart 2 indicates that all three wealth proxies behave in much the same way over 1959-85. Each variable rises in a smooth fashion at about the same growth rate.

\footnotetext{
${ }^{26}$ See, for example, Meltzer (1963), Brunner and Meltzer (1963), Chow (1966), Laidler (1966), Laumas and Spencer (1980), Mankiw and Summers (1986) and Rasche (1986).

${ }^{27}$ th has been suggested recentiy that "consumption is an ideal proxy (for permanent income) since it is proportionat to this unobserved variable. Indeed, it has often been noted that the procyclical behavior of the velocity of money is evidence for a permanent income view of money demand, since the ratio of GNP to consumption is also procyclical." Mankiw and Summers (1986), p. 416. See, in addition, Friedman and Schwartz (1982) who note that "income as measured by statisticians may be a defective index of wealth because it is subject to erratic year-to-year fluctuations, and a longer-term concept, like the concept of permanent income developed in connection with the theory of consumption, may be more useful." (p. 38)

${ }_{20}$ The data source for the wealth estimate is "Balance Sheets for the U.S. Economy 1946-85." It is Total Consolidated Domestic Net Assets (ine 10) minus U.S. Gold and SDR's (line 8) plus the market value of federal debt. The market value of federal debt is calculated by the method suggested by Butkiewicz (1983). See also Seater (1981).
}

The average annual growth rates of these variables are presented in table 1 along with the average annual growth rate of current income. The growth rates across all four variables are virtually identical for the $1959-85$ period. $^{29}$

Changes in wealth help explain a decline in velocity if wealth rises relative to current income. The data presented in table 1 give no indication that this occurred during $1982-85$, the period of declining velocity. In fact, the growth rate of physical nonhuman wealth actually fell relative to the growth of current income from 1982-85. Thus, changes in this estimate of national wealth do not help explain the decline in the income velocity of money that began in 1982. Other investigators have found similar results, ${ }^{30}$

The average growth rates of expected income $\left(\dot{Y}^{1}\right)$ and permanent income $\left\langle\dot{Y}^{p}\right\rangle$ are somewhat greater than the average growth rate of current income $\left(\dot{Y}^{c}\right)$ during 1982-85. The averages of the quarterly differences between these growth rates and the growth rate of current income, however, are not significantly different from zero in a statistical sense..$^{3 t}$ The small positive differences that are observed are likely the result of chance variation in the data.

On net, then, table 1 indicates that none of the three wealth measures rose significantly relative to current

\footnotetext{
${ }^{29}$ This result is expected for the growth rates of $Y^{\circ}$ and $Y^{c}$ over long periods. Recall that $Y^{\circ}$ is generated from a time-series model of $Y^{c}$ which is a sophisticated technique for estimating the trend of $Y$.

39 See, for example, Rasche (1986), pp. 50 and 94

${ }^{31}$ The $t$-ratio is .33 for the average of the differences between $Y^{\circ}$ and $\hat{Y}_{c}$ for the $1982-85$ period. The t-ratio is 1.12 for the average of the differences between $\dot{Y}^{\circ}$ and $\dot{Y}^{\circ}$ for the $1982-85$ period. Both are insignificant at the 5 percent level.
} 


\section{Chart 3}

\section{Velocity and Stock Market Measures of $Y^{C} / W$}

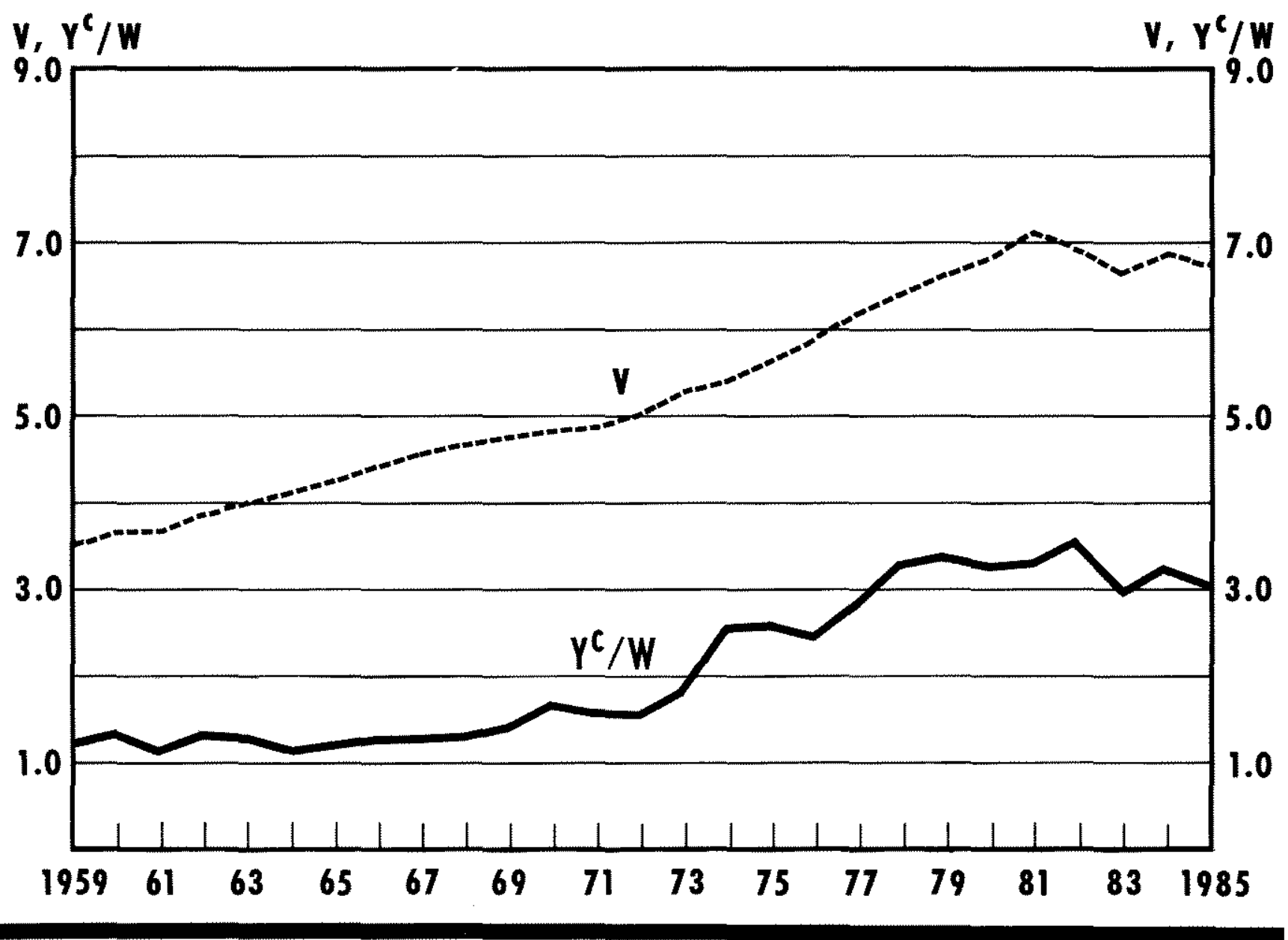

income during the 1982-85 period. Consequently changes in these measures of wealth do not help explain the decline in the income velocity of money that began in 1982

\section{A Stock Market Wealth Measure}

The conclusion that wealth has not increased relative to current income since 1981 appears to conflict with the recent behavior of the values of common stock. This narrow measure of wealth has received an increasing amount of attention, especially as various indexes of stock market values have risen to record high levels.

Common stock values of publicly traded firms are a precise measure of the capital values of the firms. Chart 3 examines the behavior of one measure of the ratio of current income to the capital values of publicly traded firms and compares this to the behavior of income velocity over $1959-85$. The measure used in chart 3 is the ratio of current income to the market value of stocks included in the Standard and Poor's 500 composite stock index. ${ }^{32}$

Chart 3 indicates that both the ratio of current income to stock market wealth and velocity have declined from 1982-85. At first glance, it appears that the recent decline in velocity may be the result of an increase in wealth relative to current income.

32Hamburger (1977 and 1983) uses the ratio of dividends paid (a measure of the current income generated by the capital of the firms) to the market value of stocks in his estimates of money demand. Hamburger's ratio behaves similarly to the ratio shown in chart 3 . 
Looking at the entire period shown in chart 3 , however, there does not appear to be a close relationship between $V$ and this income/wealth ratio. For example, the ratio did not change much from 1959 to 1969 or from 1978 to 1981, yet velocity rose. Except for the years $1973-74$ and $1977-78$, the income to wealth ratio appears to move "sideways" while velocity continuously rises over the whole period until 1981. Although other things that influenced velocity over the period shown in chart 3 were no doubt changing, perhaps markedly, it is still interesting to note that the simple correlation coefficient between changes in the income-wealth ratio and changes in velocity is .17 , which is not significantly different from zero.

\section{SUMMARY}

The income velocity of money - the ratio of GNP to M1 - has behaved differently since 1981 than it had over the previous 30 years. This paper discusses the portfolio approach to money demand, which suggests that money demand is more closely related to wealth than to current income. The portfolio theory implies that, when wealth increases relative to current income, income velocity falls, other things the same. Therefore, if the theory is valid, a substantial increase in wealth since 1981 would serve as a possible explanation of the recent fall in velocity.

The paper examines the behavior of current income relative to alternative measures of wealth. With one exception, a stock market wealth measure, the wealth measures examined here did not increase significantly relative to current income during 1982-85.

Moreover, while the ratio of current income to the stock market measure of wealth declined after 1982, the behavior of this ratio over longer periods does not appear to be related to the behavior of velocity. Thus, the evidence suggests that the decline in the income velocity of money since 1981 cannot be attributed solely to an increase in these measures of wealth.

\section{REFERENCES}

Alchian, Armen, and Willam R. Allen. Exchange and Production: Competition, Coordination and Control, 2nd ed., (Wadsworth, 1977), pp. 69-70, 160-61, 163, 165.

"Balance Sheets For the U.S. Economy 1946-85" (Board of Governors of the Federal Reserve System, Washington, D.C.).

Barro, Robert J. "Are Government Bonds Net Wealth?" Joumal of Political Economy (November/December 1974), pp. 1095-1117.

Brunner, Karl, and Meltzer, Allan H. "Predicting Velocity: Implications for Theory and Policy," Joumal of Finance (May 1963), pp. $319-54$.
Butkiewicz, James L. "The Market Value of Outstanding Government Debt: Comment," Joumal of Monetary Economics (May 1983), pp. 373-79.

Chow, Gregory C. "On the Long-Run and Shott-Run Demand for Money," Joumal of Political Economy (April 1966), pp. 111-31.

Fisher, Irving. The Theory of Interest (Kelley and Millman, 1954), pp. $3-58,61$, and $206-27$.

\section{The Rate of Interest (Macmillan, 1907), p. 213.}

1963).

Friedman, Benjamin M. "Crowding Out or Crowding In? Economic Consequences of Financing Government Deficits," Brookings Papers on Economic Activity (3/1978), pp. 593-641.

Friedman, Milton. "The Quantity Theory of Money - A Restatement," Studies in the Quantity Theory of Money (University of Chicago Press, 1956), pp. 3-21.

Friedman, Milton, and Anna J. Schwartz. A Monetary History of the United States, 1867-1960 (Princeton University Press, 1963).

Monetary Trends in the United States and United Kingdom, 1867-1975 (Chicago University Press, 1982), chapters 2, 5 and 6 .

Goldsmith, Raymond W. "National Wealth," Intemational Encyclopedia of the Social Sciences (Macmillan Co., 1968), pp. 50-59.

A Study of Saving in the United States (Princeton University Press, 1955)

. The National Wealth of the United States in the Post-War Period (Princeton University Press, 1962).

Hafer, R. W., and Scott E. Hein. "Evidence on the Temporal Stability of the Demand for Money Relationship in the United States," this Review (December 1979), pp. 3-14.

Hamburger, Michael J. "The Demand for Money in an Open Economy: Germany and the United Kingdom," Joumal of Monetary Economics (January 1977), pp. 25-40.

"Recent Velocity Behavior, The Demand for Money and Monetary Policy," Monetary Targeting and Velocity (Federal Reserve Bank of San Francisco, 1983), pp. 108-28.

Johnson, Harry G. Essays in Monetary Economics (Harvard University Press, 1969), pp. v-vili and 161-78.

Judd, John $P_{\text {., }}$ and John L. Scadding. "The Search for a Stable Money Demand Function: A Survey of the Post-1973 Literature," Joumal of Economic Lterature (September 1982), pp. 993-1023.

Knight, Frank $\mathrm{H}$. "The Business Cycle, Interest, and Money: A Methodological Approach," Review of Economic Statistics (May 1941), pp. 202-26.

Kormendi, Roger C. "Government Debt, Government Spending, and Private Sector Behavior," American Economic Review (December 1983), pp. 994-1010.

Kopcke, Richard W. "How Erratic is Money Growth?" New England Economic Review, Federal Reserve Bank of Boston (May/June 1986), pp. 3-20.

Laidler, David E. W. The Demand for Money: Theories, Evidence, and Problems, 3rd ed., (Harper and Row, 1985).

"Some Evidence on the Demand for Money," Joumal of Political Economy (February 1966), pp. 55-68.

Laumas, G. S., and David E. Spencer. "The Stability of the Demand for Money: Evidence From the Post-1973 Period," The Review of Economics Statistics (August 1980), pp. 455-59.

Mankiw, N. Gregory, and Lawrence H. Summers. "Money Demand and the Effects of Fiscal Policies," Journal of Money, Credit and Banking (November 1986), pp. 415-29. 
Meltzer, Alan H. "The Demand for Money: The Evidence from the Time Series," Joumal of Political Economy (June 1963), pp. 219 46

"M1 Loses Status at the Fed," New York Joumal of Commerce (une 23, 1986).

Patinkin, Don. Money, Interest, and Prices, 2nd ed. (Marper and Row, 1965).

Pesek, Boris P., and Thomas R. Saving. Money, Wealth, and Economic Theory (Macmillan, 1967), pp. 72-102.

Pindyck, Robert S., and Daniel L. Rubinfeld. Econometric Models and Economic Forecasts, 2nd ed. (McGraw-Hill, 1981).

Rasche, Robert H. "M1-Velocity and Money Demand Functions: Do Stable Relationships Exist?" Camegie-Rochester Conference on Public Policy, processed (November 21, 1986).

Seater, John J. "The Market Vatue of Outstanding Government
Debt, 1919-1975," Joumal of Monetary Economics (July 1981), pp. 85-101.

Siegel, Diane F., and Steven Strongin. "Can the Monetary Models be Fixed?" Economic Perspectives, Federal Reserve Bank of Chicago (November/December 1986), pp. 3-14.

Taylor, Herb. "What Has Happened to M1?" Business Review, Federal Reserve Bank of Philadelphia (September/October 1986), pp. $3-14$.

Tatom, John A. "Was the 1982 Velocity Decline Unusual?" this Review (August/September 1983), pp. 5-15.

Thompson, Earl A. "Debt tnstruments in Both Macroeconomic Theory and Capital Theory," American Economic Review (December 1967), pp. 1196-210.

Thornton, Daniel L. "Why Does Velocity Matter?" this Review (December 1983), pp. 5-13.

\section{Appendix}

\section{Time Series Forecasts}

A time series forecast of the GNP growth rate is used as a proxy for the expected percentage change in GNP. The model, which uses quarterly data, was estimated over the period $1 / 1959$ - IV/1985.

GNP appears to be a first-order homogeneous prom cess. The estimated time series model is reported below. Calculated t-statistics appear in parentheses, and $B$ is a backward shift operator, that is, $(1-B) x_{t}=$ $x_{1}-x_{t-\xi}$.

$$
\begin{aligned}
& (1-248 B) \Delta L \text { LGNP }=5.93+e_{1} \\
& \text { (2.63) }
\end{aligned}
$$

Chi-square $(2,24)=23.53$

This equation forecasts the growth in GNP. These forecasts were integrated to generate a forecast of the level of GNP. 